\title{
Selected physiological effects of boron compounds for animals and humans. A review
}

\author{
M. Białek ${ }^{1}$, M. Czauderna ${ }^{1,3}$, K.A. Krajewska ${ }^{1}$, W. Przybylski ${ }^{2}$ \\ ${ }^{1}$ The Kielanowski Institute of Animal Physiology and Nutrition, Polish Academy of Sciences, \\ Instytucka 3, 05-110 Jabłonna, Poland \\ ${ }^{2}$ Warsaw University of Life Sciences, Faculty of Human Nutrition and Consumer Sciences, \\ Nowoursynowska 159c, 02-776 Warszawa, Poland
}

KEY WORDS: boron, enzymes, farm animals, hormones, people, physiological functions

Received: $\quad 11$ June 2019

Revised: 22 November 2019

Accepted: 5 December 2019

${ }^{3}$ Corresponding author:

e-mail: m.czauderna@ifzz.pl
ABSTRACT. Boron is a metalloid that plays an important role in the functioning of cell membrane, enzymatic reactions and the hormonal and mineral metabolism of animals. Boron is also thought to be an essential metalloid for animals. Boron compounds have a wide range of physiological effects in living organisms when occurring at low levels, while toxic at high levels. Boron does not accumulate efficiently in soft tissues; but it accumulates efficiently in the bones. More than $90 \%$ of the excessive amount of borate in mammals is excreted as boric acid in the urine. Boron has an impact on skeletal metabolism, thus it affects bone growth and compositional properties of soft tissues in animals and humans. Boron-rich diets have a beneficial impact on the calcification and maintenance of mammalian bones, central nervous system functions, and also play a positive role in maintaining the structural integrity and function of cell membranes. Borate in the perinatal diet of cattle improves animal metabolic status stimulating glucose metabolism and limiting lipolysis intensity. The main purpose of the present review was to recapitulate the most important findings regarding the biochemical mechanisms responsible for beneficial physiological effects of boron in animals and humans.

\section{Introduction}

Dietary boron supplementation affects the metabolism of substances such as $\mathrm{Ca}, \mathrm{Mg}$, triglycerides, glucose, amino acids, reactive oxygen and nitrogen species, hormones such as $17 \beta$-estradiol, calcitonin, 25-hydroxy-cholecalciferol (Nielsen, 2002; 2014; Kot, 2009). Moreover, some boron-compounds (like calcium fructoborate, boric acid or borax) have antioxidant or/and anti-inflammatory properties (Scorei, 2011). On the other hand, boron-deficient diets have been linked to many pathological conditions, including several forms of osteoporosis and osteoarthritis and cancers (Geyikoglu and Turkez, 2008; Horiguchi et al., 2015). Interestingly, the effects of boron compounds on carcinogenesis are extensively studied; numerous current studies define biological effects of boron (like anticancerogenic activity) based on cell cultures, metabolic and cellular processes in animals (Bakke, 1991; Rudd, 1991; Penland, 1998; Hunt and Idso, 1999; Hunt, 2003; Geyikoglu and Turkez, 2008; Doğan et al., 2017).

In previous systematic investigations on the biological significance of boron to nutritional, hormonal, metabolic and physiological processes it was also documented that boron supports normal biological functions of higher animals and humans (Kabu and Akosman, 2013). However, the nesessity of boron 
for humans has not been definitively reported, despite this boron is considered as a probably essential element by the World Health Organization (WHO, 1996). Therefore, the principal purpose of this review was to recapitulate the most important findings about the biochemical mechanisms responsible for the beneficial physiologic effects of boron especially in reference to farm animals (like ruminants, pigs or poultry). Moreover, the aim of the present review was to summarize progress made in understanding biological roles of boron in animal and human nutrition.

\section{General properties of boron, its characteristics and occurrence}

Boron was discovered as an element by Sir Humphry Davy, Gay-Lussac and Thenard in 1808, whereas pure boron was first produced by the American chemist Ezekiel Weintraub in 1909 (Bolaños et al., 2004). Boron, an unequal metalloid with atomic number 5 , is a semiconductive element with properties of a nonmetal and a metal. Boron, which bears the symbol B in the periodic table, is similar to carbon in its chemical capability to form stable molecular covalently bonded networks. Boron is very rare in the Universe and the Solar System due to trace formation in the Big Bang and in stars. Boron is formed in small amounts in cosmic ray spallation nucleosynthesis and may be found uncombined in meteoroid materials and cosmic dust. It is suggested that boron and molybdenum catalysed the synthesis of RNA on Mars with life being transported to Earth via a meteorite around 3 billion years ago. In the high oxygen environment of Earth, boron is oxidized to borate, usually as alkali or alkaline earth borates or as boric acid (Kabu and Akosman, 2013). Therefore, this very rare element does not appear on Earth in elemental form. Thus, boron is a naturally occurring microelement that is found in the form of borates in sedimentary rocks, shale, oceans, coal and soil. This microelement is widely dispersed in the Earth's crust, with contents of $\sim 4.5 \mathrm{mg} \mathrm{B} / 1$ in the ocean and $\sim 10 \mathrm{mg} \mathrm{B} / \mathrm{kg}$ in the Earth's crust (range: $\sim 5 \mathrm{mg} \mathrm{B} / \mathrm{kg}$ in basalts to $\sim 100 \mathrm{mg} \mathrm{B} / \mathrm{kg}$ in shales). The most important world boron reserves are located in the USA and Turkey, together with its deposits found in Russia, China, Chile, Argentina, Peru, Iraq, Syria, Egypt, Libya and Morocco (Tanaka and Fujiwara, 2008). Boron naturally occurs as isotopes ${ }^{10} \mathrm{~B}$ and ${ }^{11} \mathrm{~B}$, with the latter making up $\sim 80 \%$ of natural boron isomer mixture. ${ }^{10} \mathrm{~B}$ isotope has a number of uses as a neutron-capturing agent, e.g., within the core of nuclear reactors, as well as in boron neutron capture therapy used in the experimental treatment of some human cancers (Hopewell et al., 2011; Horiguchi et al., 2015).

Boron is the lightest element having an electron in a p-orbital in its ground state (Davidson et al., 2000). The chemically properties of boron resembles that of silicon more than aluminium. Although, boron is similar to carbon in its uncial capability to form stable covalently bonded molecular networks. In the most popular compounds (like oxides, sulphides, nitrides or halides), boron has the formal oxidation state III. However, boron forms a lot of compounds with formal oxidation state less than three (like B(I) or $\mathrm{B}$ (II) halides). Interestingly, metal borides contain boron in negative oxidation states (e.g., $\mathrm{MgB}_{2}$ ); each boron atom has a formal -1 charge, while metal atom has a formal +1 charge (e.g., $\mathrm{Mg}$ in $\mathrm{MgB}_{2}$ has the charge of +2 ). The most unusual compounds of boron are the hydrides, e.g., dodecaborate $\left(\left[\mathrm{B}_{12} \mathrm{H}_{12}\right]^{2-}\right)$, decaborane $\left(\mathrm{B}_{10} \mathrm{H}_{14}\right)$ and carboranes $\left(\mathrm{C}_{2} \mathrm{~B}_{10} \mathrm{H}_{12}\right)$. At present, a large number of organic boron compounds is also known like alkylideneboranes, carboranes, phenylborate-compounds and mono- or di-sugar-borate esters. Organic boron (III) compounds are usually tetrahedral or trigonal planar, e.g., tetra-phenylborate $\left(\left[\mathrm{B}\left(\mathrm{C}_{6} \mathrm{H}_{5}\right)_{4}\right]^{-}\right)$or triphenylborane $\left(\mathrm{B}\left(\mathrm{C}_{6} \mathrm{H}_{5}\right)_{3}\right)$. Furthermore, multiple boron atoms combining with each other have a tendency to form dodecahedral or icosahedral structures composed of boron atoms, or with varying numbers of carbon heteroatoms.

Boron, like Se, $\mathrm{Zn}$ or $\mathrm{Cu}$ (Rozbicka-Wieczorek et al., 2016; Czauderna et al., 2017), was classified as a trace element by the WHO in 1980 (WHO, 1996). Currently, there is a need to re-classify boron as an essential microelement with the recently discovered beneficial impact on human health when consumed at Tolerable Chronic Intake Level (Nielsen, 2014).

Boron is a chemically dynamic trace element that forms, usually with other elements, $\sim 280$ mineral species. Themostimportant minerals and commercial boron products are borax, borax pentahydrate, sodium perborate, colemanite, boric acid and ulexite. Boron compounds are not degraded or transformed in the environment. However, transformations of boron species are affected by changes in the natural environment (like moisture level or soil $\mathrm{pH}$ ). The level of boron in plants is affected by soil boron content and soil pH (Kabata-Pendias, 2000). Thus, different forage plants are able to provide diverse levels of boron required for growth and reproduction of various farm animals. For example, alfalfa, clover and other legumes require $20-70 \mathrm{mg} \mathrm{B} / \mathrm{kg}$ dry mass (DM) in plant to prevent boron deficiency in farm 
animals (like pigs or horses). On the other hand, grasses and grain crops (monocotyledon species) require only $5-10 \mathrm{mg} \mathrm{B} / \mathrm{kg} \mathrm{DM}$ in plant to prevent boron deficiency in ruminants (Fry et al., 2010).

Recent studies strongly documented that only plants have the ability to metabolize inorganic boron compounds (like boric acid or borates) and to convert these boron compounds into mono- or di-sugar-borate esters (SBEs), e.g., glucose and fructose borate esters, bis-sucrose borate esters, pectic polysaccharide borate esters or sugar alcohol borate esters (Hunter et al., 2019). In contrast, animals and humans do not have the capacity to transform boric acid or borates into SBEs (Hunter et al., 2019). SBEs are found in herbs, seeds, fresh leafy vegetables, fruits, legumes, certain nuts, wine, cider, beer and especially in flaxseed sprouts, dandelion root and raisin. SBEs of plant origin are efficiently assimilated by human and animal cells. The nutritional significance of SBEs in the prophylaxis of chronic diseases has been acknowledged in the global community. SBEs in the diet stimulate bone mineralization by participating in the homeostatic regulation of serum levels of testosterone and estrogen, and metabolism of mineral and Ca components of bones (Soriano-Ursúa et al., 2014). The physiological effect of SBEs is more pronounced during concurrent nutritional insult, particularly vita$\min \mathrm{D}_{3}$ deficiency.

Vegetables, fruits and honey are the basic sources of fructoborates (fructoborate esters, FB), mainly in the form of calcium $\left(\mathrm{Ca}^{2+}\right)$ fructoborate complex (Pietrzkowski et al., 2014; 2018; Donoiu et al., 2018). Fructoborates have positive synergic interactions with ions of $\mathrm{Ca}, \mathrm{Mg}, \mathrm{Zn}, \mathrm{Fe}$ and $\mathrm{Cu}$; FB have a better interaction capacity with glycoproteins versus that of the boric acid or borate (Mogoşanu et al., 2016; Hunter et al., 2019). In contrast, FB are antagonized by $\mathrm{Si}$ (as orthosilicic acid), iodine and fluoride (Hunter et al., 2019). Fructoborate complexes with metal ions like $\mathrm{Zn}, \mathrm{Mg}, \mathrm{Fe}$ or $\mathrm{Cu}$ and a protonated diester fructoborates (HBF; the FB complex with $\mathrm{H}^{+}$) have negligible physiological significance as compared to calcium FB complex (CaFB). A novel zinc-boron complex ( $\mathrm{ZnFB}$ ) reveals low cytotoxic effect (Hunter et al., 2019). It must be stated that $\mathrm{CaFB}\left(\mathrm{Ca}\left[\left(\mathrm{C}_{6} \mathrm{H}_{10} \mathrm{O}_{6}\right)_{2} \mathrm{~B}\right]_{2} \cdot 4 \mathrm{H}_{2} \mathrm{O}\right)$ is the most common natural sugar-borate ester complex, typically manifested as the specific bis-fructose ester (Tepedelen et al., 2017). CaFB has been usually isolated from plants but it can be also produced by chemical synthesis (Scorei and Rotaru, 2011). CaFB is an excellent source of soluble boron in three forms: diester, monoester and boric acid (Mogoşanu et al.,
2016). CaFB in human and animal diets reveals many beneficial physiological properties that might have a therapeutic potential (e.g., anti-inflammatory antioxidant, antiosteoporosis and antitumor) (Scorei, 2011; Scorei and Rotaru, 2011; Militaru et al., 2013; Pietrzkowski et al., 2014; Rogoveanu et al., 2015). In fact, CaFB prevents the harmful effects of vitamin $\mathrm{D}_{3}$ deficiency and improves the metabolism of vitamin $\mathrm{D}_{3}$ after dietary boron supplementation. $\mathrm{CaFB}$ acts as an antioxidant and stimulates the overexpression of apoptosis-related proteins and eventual apoptosis. Diets supplemented with $\mathrm{CaFB}$ and n-3 polyunsaturated fatty acids (n-3PUFA) improve farm animals' health condition and the production quality. In the USA, CaFB is applied as a supplement into human diets for bone health and modulation of symptoms of arthritis and joint degeneration. Moreover, it was revealed that $\mathrm{CaFB}$ added to human diets has a beneficial impact on various anti-inflammatory processes (Hunter et al., 2019). CaFB regulates macrophage production of inflammatory mediators, inhibits the evolution of diseases associated with endotoxins and suppresses cytokine formation. It has been demonstrated that $\mathrm{CaFB}$ is an effective superoxide ion scavenger and may have anti-inflammatory activity. In humans and other mammals, the anti-inflammatory activity of $\mathrm{CaFB}$ might be the result of the modulation of serine proteases discharged by inflammation-activated leukocytes: a) by the modulated leukotriene synthesis; and b) by reduced concentrations of reactive oxygen species created during neutrophils respiratory burst. Moreover, CaFB may also modulate the biosynthesis of proinflammatory prostaglandins derived from arachidonic acid.

To generalize, plants have higher boron concentrations (from 0.1 to $0.6 \mathrm{mg} \mathrm{B} / 100 \mathrm{~g}$ ) than food of animal origin (from 0.01 to $0.06 \mathrm{mg} \mathrm{B} / 100 \mathrm{~g}$ ). Another important source of boron compounds is water where the concentration of this element varies according to geographic location. Boron compounds are ingested with food on a daily basis. Humans consume plenty of products containing boron compounds; these boron compounds exist abundantly in fruits, vegetables, nuts and their byproducts (Baker et al., 2011; Uluisik et al., 2018). It has been established that for healthy humans boron concentration in whole-blood is $0.020-0.078 \mu \mathrm{g} /$ $\mathrm{ml}$ for men and $0.019-0.062 \mu \mathrm{g} / \mathrm{ml}$ for women. Interestingly, the adequate reference range for hair boron concentration is $0.77-6.51 \mu / \mathrm{g}$ for men and $0.47-3.89 \mu \mathrm{g} / \mathrm{g}$ for women (Devirian and Volpe, 2003). 
When administered to healthy humans and higher animals, inorganic boron compounds are rapidly absorbed and then metabolized into boric acids and assimilated through mucosal surfaces. Orally ingested boric acid or borates are readily and nearly completely $(>90 \%)$ absorbed from the gastrointestinal tract; boric acid or borates are not degraded in the body. Indeed, catabolism may not be feasible because of a huge amount of energy $(523 \mathrm{~kJ} / \mathrm{Mol})$ that is apparently required to break the boron-oxygen bonds. Boric acid or borates can form complexes with various biomolecules (like carbohydrates or proteins) in mammal tissue. Thus, these boron compounds have a considerable affinity for thiol, amino and hydroxyl groups of biomolecules. Complex formation between borate compounds and these biomolecules in mammal tissues is reversible and concentration-dependent (U.S. Department of Health and Human Services, 2010). The electron structure of boron atom makes boron containing molecules electrophilic with the trigonal planar structures. The additional bond with boron allows the formation of nucleophilic tetravalent anions with tetrahedral structures. Some of boron containing molecules are analogues of natural biomolecules and have therapeutic properties. These boron containing molecules include an antibacterial and antimalarial agent diazaborine, antibacterial diphenyl borinic esters, antibacterial oxazaborolidines, antifungal agent benzoxaborole or a B-N bond containing estrogen receptor modulator (Scorei, 2011). Recent studies indicate that the nicotinamide adenine dinucleotide (NAD) and nicotinamide adenine dinucleotide phosphate (NADPH) ribose contain components that have a very strong affinity for boron and these biomolecules are very active in energy metabolism (Dessordi et al., 2017). Therefore, the connection between the bio-molecules and boron may affect some processes of specific metabolic pathways. Thus, the chemical structure of boron compound allows to react with many other enzymes and metabolites, which can change the mineral and energy metabolism in ruminants (Sizmaz et al., 2017), monogastric animals as well as in humans (Hunt, 2012). Dietary boron does not efficiently accumulate in soft tissues of mammals, which has been documented in earlier studies by lack of considerable incorporation of boron in testis and epididymis (U.S. Department of Health and Human Services, 2010). On the contrary, dietary boron efficiently accumulates in bones, reaching steady-state concentrations approximately four-fold higher than plasma concentrations after 1-4 weeks, depending on the amount of boron in diets (U.S. Department of Health and Human Services, 2010). In animal and human bodies about $96 \%$ of boron is present as an unchanged boric acid $\left(\mathrm{B}(\mathrm{OH})_{3} /\right.$ $\mathrm{H}_{3} \mathrm{BO}_{3}$ ) and as a small concentration of borate anion $\left(\mathrm{B}(\mathrm{OH})_{4}^{-}\right)$(Uluisik et al., 2018). Fortunately, boron is not deposited in any edible tissues of farm animals or animal products to an extent that would be of a potential toxicological concern for humans. More than $90 \%$ of excessive amounts of borate in healthy human or animals are excreted (by glomerular filtration) as boric acid in the urine, regardless of the route of exposure or administration. In the case of humans, excretion of boron is rapid, with a half-life of boron elimination of $24 \mathrm{~h}$ or less (U.S. Department of Health and Human Services, 2010). For instance, boron is cleared from the plasma with a half-life of about $21 \mathrm{~h}$. The elimination kinetics of boron from human bone is different from soft tissues and body fluids. However, regarding humans with kidney problems, boron intake, as with any mineral supplement (especially potassium), should be carefully monitored as impaired kidney function could reduce excretion, resulting in excessive accumulation of boron in the human body. Thus, alterations of renal function result in increased residence time of boron in mammal tissues. Decrements of renal function will increase its internal exposure and may predispose affected individuals to greater risk.

In humans oral exposures to high concentrations of boron (as borate or boric acid) have resulted in a minute or unnoticeable toxicity, as seen in poisonings up to $88 \mathrm{~g}$ of boron, while $90 \%$ of the cases were asymptomatic (Litovitz et al., 1988; Restuccio et al., 1992). Chronic exposure to boron compounds ( $\geq 84 \mathrm{mg} \mathrm{B} / \mathrm{kg}$ body weight (BW) per day) stimulates neurological, gastrointestinal, cardiovascular and hepatic diseases, as well as diarrhoea, anorexia, kidney damage and testicular atrophy. Other symptoms of boron poisoning include rash, light-headedness, headache and lethargy. Moreover, toxic doses of boron (from 100- to 1000-fold greater than physiological) have been shown to cause specific adverse effects in the male reproductive tract in the case of all animal species. In fact, it has been observed that the dose of $58.5 \mathrm{mg} \mathrm{B} / \mathrm{kg} \mathrm{BW}$ per day resulted in testicular atrophy and complete suppression of fertility of laboratory rats (Van Paemel et al., 2010). Furthermore, signs of boron toxicosis include decreased body, spleen, kidneys and pancreas weight. Tolerable upper intake levels (UL) of boron are shown in Table 1. The UL of boron is the highest content 
Table 1. Tolerable upper intake levels (UL) of boron ${ }^{1,2}$

\begin{tabular}{|c|c|c|c|}
\hline $\begin{array}{l}\text { Life stage } \\
\text { group }\end{array}$ & $\begin{array}{l}\text { Boron } \\
\mathrm{mg} / \text { day }\end{array}$ & $\begin{array}{l}\text { Life stage } \\
\text { group }\end{array}$ & $\begin{array}{l}\text { Boron } \\
\mathrm{mg} / \text { day }\end{array}$ \\
\hline Infants & & Females & \\
\hline 0 to 6 months & ND & 9 to 13 years & 11 \\
\hline \multirow[t]{2}{*}{6 to 12 months } & ND & 14 to 18 years & 17 \\
\hline & & 19 to 30 years & 20 \\
\hline Children & & 31 to 50 years & 20 \\
\hline 1 to 3 years & 3 & 51 to 70 years & 20 \\
\hline \multirow[t]{2}{*}{4 to 8 years } & 6 & $>70$ years & 20 \\
\hline & & Pregnancy & \\
\hline Males & & 14 to 18 years & 11 \\
\hline 9 to 13 years & 11 & 19 to 30 years & 20 \\
\hline 14 to 18 years & 17 & 31 to 50 years & 20 \\
\hline 19 to 30 years & 20 & Lactation & \\
\hline 31 to 50 years & 20 & 14 to 18 years & 11 \\
\hline 51 to 70 years & 20 & 19 to 30 years & 20 \\
\hline$>70$ years & 20 & 31 to 50 years & 20 \\
\hline
\end{tabular}

1 the UL represents total intake from food, water, and supplements; 2 these data were obtained from www.nap.edu: 'Dietary Reference Intakes (DRIs): Tolerable Upper Intake Levels, Elements Food and Nutrition Board'; Institute of Medicine, National Academies, Washington, DC (USA); ND - no data

of daily nutrient intake that is likely to pose no risk of adverse health effects to humans in the general population. On the other hand, the acute lethal dose of inorganic boron compounds for humans is estimated to be in the range of $0.4-0.9 \mathrm{~g} / \mathrm{kg} \mathrm{BW}$ (EPA, 2004). For boric acid, the minimum lethal dose by oral exposure is about 2-3 g for infants, 5-6 g for children and 15-20 g for adults (EPA, 2004; U.S. Department of Health and Human Services, 2010).

In vitro and in vivo studies document that boron compounds (like boric acid) reveal an affinity for cis-hydroxyl groups and this may account for the mechanism by which boric acid exhibits some of its biologically important effects (Kabu and Akosman, 2013). Indeed, the boron atom is small in comparison with other IIIA elements (like Al, Ga, In or Tl) in the periodic table. Boron, with three valence electrons, acts as weak Lewis acid (a compound accepts a pair of nonbonding electrons), efficiently accepting hydroxyl anions (i.e. Lewis base donates a pair of nonbonding electrons). Therefore, boron complexes with organic molecules possessing hydroxyl groups, especially those with more than two hydroxyl groups, react very efficiently. As a consequence, boron effectively reacts with molecules of biological interest (like pyridine nucleotides, riboflavin, pyridoxine, dehydroascorbic acid or polysaccharides) (Uluisik et al., 2018). Thus, it can be stated that formed organoboron complexes, which contain $\mathrm{B}-\mathrm{O}$ or $\mathrm{B}-\mathrm{N}$ bonds like orthoborates, fulfil plenty of important functions within human, animal and plant tissues. In fact, numerous studies on the biological significance of boron show that boron is an essential element for higher plants (Kabu and Akosman, 2013). Consistently, these studies revealed that boron is important in sugar transport, carbohydrate metabolism, RNA metabolism, membrane transport, respiration and bioaccumulation of other biologically essential elements. Minute amounts of boron compounds play a strengthening role in the cell walls of all plants (Blevins and Lukaszewski, 1998; Kabu et al., 2015; Sizmaz et al., 2017). In fact, very important elements for animals and higher plants growth are $\mathrm{N}, \mathrm{P}, \mathrm{K}, \mathrm{Ca}, \mathrm{Mg}, \mathrm{S}, \mathrm{Cl}, \mathrm{Fe}, \mathrm{Mg}, \mathrm{Zn}, \mathrm{Cu}$, Mo and Ni (Rozbicka-Wieczorek et al., 2016). In addition to these essential elements, there are also listed other beneficial elements as $\mathrm{Si}, \mathrm{Na}, \mathrm{Co}$ and $\mathrm{Se}$ (Czauderna et al., 2017), which promote growth but are not absolutely necessary for completion of the plant life cycle (Blevins and Lukaszewski, 1998). Furthermore, there are many evidences that boron is an essential element for embryological development of frogs and fish which does not proceed normally in the absence of dietary boron.

\section{Boron compounds in embryogenesis and reproduction}

It is well recognized that boron is required to complete the life cycle of some species (Abdelnour et al., 2018). The most important evidences of boronrequirement comes from preliminary investigations on zebrafish (Danio rerio) and particular frog species (Xenopus laevis) (Nielsen, 2002). It was revealed that more than $80 \%$ of embryos from frogs fed for 120 days a boron-deficient diet died before $96 \mathrm{~h}$ of development (Fort et al., 1999b). On the other hand, survival of embryos from frogs fed enriched boron diet at $96 \mathrm{~h}(1.85 \mathrm{mg} / \mathrm{kg})$ exceeded $75 \%$. Subsequent studies document that both, 28 and 120 days of boron deprivation, affected the reproductive system of the adult male and female frogs; testis as well as ovaries were atrophied (Fort et al., 1999a). Borondeprived male frogs exhibited decreased sperm counts and sperm dysmorphology. Moreover, in the female frogs, boron deprivation impaired oocyte maturation. On the other hand, culturing stage 1 and 2 oocytes from boron-adequate frogs in a medium containing progesterone resulted in successful maturation to stage 5 or 6 oocytes.

Unfortunately, investigations carried out on mammals have not been as definitive as those on frogs. However, there are some studies showing that 
low boron deficiency impairs early development of rodents; and that boron is beneficial for pig or ruminant reproductive process (Armstrong et al., 2002; Kabu and Civelek, 2012; Kabu and Akosman, 2013; Kabu et al., 2013). Indeed, the number of implantation sites and foetuses was slightly higher in rats fed $2 \mu \mathrm{g} \mathrm{B} / \mathrm{g}$ diet than in rats fed a low boron diet $(\sim 0.04 \mathrm{ppm} \mathrm{B})$. Recent studies document that boron supplementation plays a vital role in embryogenesis, immunity and psychomotor functions (Pizzorno, 2015; Dessordi et al., 2017). Conversely, low boron diets ( $\sim 2 \mu \mathrm{g} \mathrm{B} / \mathrm{g}$ diet) have no noticeable effects on foetal growth and development (Lanoue et al., 1998). Fortunately, the most extensive evidence for boron requirement is based on studies on gilts (Amstrong et al., 2002). Diets enriched with $5 \mathrm{ppm}$ of boron (as sodium borate) tend to increase the number of live embryos in the uterus at day 35 of gestation and decrease the number of mummified foetuses at parturition. Moreover, diets supplemented with boron positively influence the birth weight and significantly increase pig weaning weight. Furthermore, diets enriched with boron decrease $\mathrm{Ca}$ concentrations in the embryo, oviduct and uterus and $\mathrm{P}$ concentrations in the pig ovary, uterus and liver. Similarly, dietary sodium borate ( $30 \mathrm{~g} \mathrm{~B}$ per day) improves the metabolic status of cattle during periparturient period by stimulating glucose metabolism, limiting lipolysis intensity and increasing serum concentrations of $\mathrm{P}, \mathrm{Mg}$ and $\mathrm{Ca}$, hence preventing metabolic ailments in dairy cattle (Kabu and Civelek, 2012; Kabu and Akosman, 2013; Kabu et al., 2013; 2015; Sizmaz et al., 2017).

Interestingly, laboratory studies reveal that plasma testosterone concentrations increase in rats fed $2 \mathrm{mg}$ B per day, but raising boron dose to 12.5 or $25 \mathrm{mg}$ per day results in lower plasma testosterone contents (Naghii and Samman, 1996; 1997). Similarly, testicular testosterone contents decrease with increasing boron dose in diets. It seems that Leydig cells, responsible for biosynthesis of testosterone, are intact in laboratory rats fed $25 \mathrm{mg}$ B per day in spite of testicular atrophy. Moreover, testicular histopathology was found in rats fed 23-30 mg B per day for 90 days, and atrophy when boron content in the testes was greater than $20 \mathrm{ppm}$ (U.S. Department of Health and Human Services, 2010). In multigeneration studies of subchronic and chronic toxicity of boron (as borax or boric acid) no adverse effects on reproduction or gross pathology were found in Sprague-Dawley rats dosed with 5.9 or $17.5 \mathrm{mg} \mathrm{B} / \mathrm{kg}$ per day that were examined to the F3 generation. Litter size, appearance and weight of progeny were normal when compared with control rats. On the other hand, the experimental rats receiving $58.5 \mathrm{mg} \mathrm{B} / \mathrm{kg}$ per day were found sterile. In these rat groups, males showed lack of spermatozoa in atrophied testes and females showed decreased ovulation in the majority of the examined ovaries. An attempt to obtain litters by mating the treated females with the males fed control diet was not successful. The lowest-observedadverse-effect level (LOAEL) of $58.5 \mathrm{mg} \mathrm{B} / \mathrm{kg}$ per day and the no-observable-adverse-effect level (NOAEL) of $17.5 \mathrm{mg} \mathrm{B} / \mathrm{kg}$ per day were identified in this investigation (U.S. Department of Health and Human Services, 2010).

\section{Dietary boron action in the body, bone growth and maintenance in mammals and poultry}

A lot of factors involved in the biological activity of boron can be found in numerous studies; of these concurrent, nutritional variables are the most important (Hunt, 1998; Rondanelli et al., 2013; Bozkurt and Küçükyilmaz, 2015; Dessordi et al., 2017). It has been confirmed that nutritional state and dietary levels of vitamin $\mathrm{D}_{3}, \mathrm{Se}, \mathrm{Ca}, \mathrm{Mg}, \mathrm{P}, \mathrm{F}$, $\mathrm{Al}, \mathrm{Mo}, \mathrm{n}$-3PUFA and proteins may have a significant impact on the biological activity of boron and levels of its supplementation (Nielsen and Penland, 1999; Armstrong and Spears, 2001; Rondanelli et al., 2013). Thus, there are many reasons for the inconsistent results of boron supplementation in eliciting beneficial responses in animals (Jin et al., 2014).

Distribution of boron in higher animals and humans appears to occur by passive diffusion throughout the body fluids. In contrast to blood and soft tissues, bones show selective uptake and remarkably longer retention times of boron. There are numerous experimental and epidemiological investigations showing the beneficial effects of both nutritional and pharmacological intakes of boron compounds, n-3 long-chain PUFA (n-3LPUFA) and conjugated PUFA on metabolic balance as well as bone formation and mineralization, bone mechanical properties and maintenance in mammals (Armstrong et al., 2000; 2002; Armstrong and Spears, 2001; Białek et al., 2017; Sizmaz et al., 2017). The research also indicate the influence of boron compounds on the response to hormones involved in bone turnover such as estrogen and vitamin $\mathrm{D}_{3}$ in higher animals and humans (Rondanelli et al., 2013; Nielsen, 2014; Bozkurt and Küçükyilmaz, 2015; Uluisik et al., 
Table 2. Boron role in animal nutrition

\begin{tabular}{|c|c|}
\hline Beneficial impact & Actions \\
\hline $\begin{array}{l}\text { Bone growth and } \\
\text { mineralization }\end{array}$ & $\begin{array}{l}\text { Boron stimulates bone mineralization by influencing serum concentra- } \\
\text { tions of estrogen and testosterone, and the utilization and metabolism } \\
\text { of } \mathrm{Ca}, \mathrm{P} \text { and other elements of bone; boron increases morphogenetic } \\
\text { proteins in bones. Boron contents in bone and blood increase with } \\
\text { age and health state and decrease with disease conditions. Boron im- } \\
\text { proves bone mechanical properties and maintenance in farm animals. } \\
\text { Boron deficiency causes osteoporosis. }\end{array}$ \\
\hline Growth performance & $\begin{array}{l}\text { Dietary boron improves feed efficiency (feed:gain ratio) in pigs; en- } \\
\text { hances nutrient digestibility and growth of animals. Dietary boron de- } \\
\text { creases a percentage of bone lipid in pigs. Appropriate supplements } \\
\text { of boron (<100 mg in litre of drinking water) improve growth of immune } \\
\text { organs in broilers; higher doses of boron ( }>200 \mathrm{mg} / \mathrm{l}) \text { inhibit growth of } \\
\text { immune organs of broilers and exhibit toxic effects. Weight gain of } \\
\text { animals was improved by boron added to diets deficient in Ca. }\end{array}$ \\
\hline
\end{tabular}

Boron in diets deficient in $\mathrm{Ca}, \mathrm{Mg}$ and/or $\mathrm{P}$

Boron as the antioxidant

Anti-inflammatory properties of boron

Effect of boron compounds on the aging
Boron added to diets deficient in $\mathrm{Ca}$ and $\mathrm{P}$ improves growth performance and some bone, serum and faecal characteristics. Boron administration elevates serum levels of $\mathrm{Ca}, \mathrm{Mg}$ and $\mathrm{P}$ in peripartum cows. Dietary boron enhances gut absorption of $\mathrm{Ca}$. Boron stimulates calcification. Boron supplementation reduces urinary $\mathrm{Ca}$ excretion.

Boron as Ca-fructoborate complex (CaFB) exhibits promising antioxidant properties. Boric acid or borate supplementation improves antioxidant defence mechanism. Boron stimulates activities of catalase, superoxide dismutase, glucose-6-phosphate dehydrogenase, glutathione-S-transferase and glutathione peroxidase enzymes. Boron detoxifies reactive oxygen (ROS) and nitrogen (RNS) species, and alleviates heat stress. Boron reduces DNA damage and lipid peroxidation.

Boron influences macrophage production of inflammatory mediators. $\mathrm{CaFB}$, boric acid or borates suppress cytokine production, and inhibit progression of endotoxin-associated diseases. As a regulator of respiratory burst by suppression of serine proteases released by inflammation activated white blood cells, boron reduces leukotriene synthesis. CaFB decreases the biosynthesis of pro-inflammatory prostaglandins derived from arachidonic acid. Boron decreases the reactive oxygen species levels within the cells. CaFB is an effective superoxide ion scavenger: CaFB inhibits interleukin (IL)-1 $\beta$, IL-6 and nitric oxide release in the culture media. CaFB increases the tumor necrosis factor-a production.

An imbalance of the homeostatic balance between removal and formation of ROS and RNS is the main cause of aging. Therefore, dietary sugar-borate esters (SBEs; CaFB in particular) provide very significant opportunities in the life extension and quality of life improvement (especially in the areas of healthier aging, bone calcification and modulation of inflammatory conditions). Dietary organic boron compound (especially SBEs) improves livestock welfare.

\section{References}

Armstrong et al., 2000; 2002; Armstrong

and Spears, 2001; Palacios, 2006; Hakki

et al., 2013; Soriano-Ursúa et al., 2014;

Mogoşanu et al., 2016; Sizmaz et al., 2017;

Hunter et al., 2019

Armstrong et al., 2000; Armstrong and Spears, 2001; Jin et al., 2014; Vijay Bhasker et al., 2016

Scorei and Rotaru, 2011; Kabu et al., 2013, 2015; Bozkurt and Küçükyilmaz, 2015; Mogoşanu et al., 2016; Hunter et al., 2019

Türkez et al., 2007; Hu et al., 2014; Ince et al., 2014; Celikezen et al., 2015; Boyacioglu et al., 2017; Abdelnour et al., 2018; Uluisik et al., 2018; Hunter et al., 2019

Hunt, 2003; 2008; Naghii et al., 2011; Scorei and Rotaru, 2011; Scorei, 2011; Nielsen, 2017; Hunter et al., 2019

Trifunovic and Larsson, 2008; Hunter et al., 2019 
activity, particularly at low dietary concentrations of $\mathrm{D}_{3}(6.25 \mu \mathrm{g} / \mathrm{kg})$. Interestingly, the relationship between dietary boron and $\mathrm{Mg}$ is more effective than the one between $\mathrm{P}$ and $\mathrm{Ca}$. Moreover, dietary boron supplementation alleviates perturbations in mineral metabolism that are especially characteristic for vitamin $\mathrm{D}_{3}$ deficiency (Bozkurt and Küçükyilmaz, 2015; Kabu et al., 2015). It has been shown that three particular mechanisms are involved in the vitamin $\mathrm{D}_{3}$-boron interaction in mammals: a) dietary boron supplementation compensates for disturbances in energy-substrate utilization; b) boron compounds enhance concentrations of macroelement in normal bones; c) higher physiological amounts of boron in diets positively influence components of bone growth cartilage. Dietary boron supplementation mitigates defects in cartilage growth, maturation and calcification induced by vitamin $\mathrm{D}_{3}$ deficiency (Kabu et al., 2015). Interestingly, it seems possible that boron-deficient diets are causal agents in KashinBeck disease which is a bone disease resulting in high incidence in China.

Similarly, boron-deficient diets decrease dry weight and concentrations of $\mathrm{Ca}, \mathrm{Cu}$ and $\mathrm{Zn}$ in femurs of poultry (e.g., chickens or turkeys). These effects are particularly significant when concentrations of vitamin $\mathrm{D}_{3}$ in diets are lower than adequate (Kot, 2009). On the other hand, broiler diets containing 60-120 ppm of boron considerably improved feed conversion ratio and growth rate of birds. Unfortunately, dietary boron may be toxic at high doses: $400 \mathrm{mg} / \mathrm{kg}$ dietary boron decreased body weight, feed consumption, egg production and egg weight of layers (Wang et al., 2014). Similarly, $160 \mathrm{mg}$ of boron (as boric acid) added to drinking tap water improved growth performance and meat quality of African ostrich chicks. On the other hand, higher concentrations of boron in drinking water decreased both: performance and meat quality of chicks (Wang et al., 2014). Past researches show that low-supplemental boric acid (especially $80 \mathrm{mg} \mathrm{B}$ per litter of water) could promote intestinal mucosal immunity; these doses of boron in drinking water could promote intestinal cell proliferation and inhibit apoptosis. On the contrary, pharmacological dosages of boric acid (320 and $640 \mathrm{mg} / \mathrm{l})$ cause destruction of the intestinal mucosal barrier function. High dose of boron in drinking water stimulates cell apoptosis but increases intestinal cell proliferation, which acts as compensatory adaptation (Sun et al., 2016). It was also found that the diets containing 50 and $100 \mathrm{mg} \mathrm{B} / \mathrm{kg}$ (nutritional dosages) significantly increased shear force of tibia and femur, shear stress of tibia and shear fracture energy of femur of chickens. Moreover, dietary boron supplementation alleviates growth cartilage abnormalities in chickens and layer hens fed diets containing marginally inadequate vitamin $\mathrm{D}_{3}$ levels (Nielsen, 2002; 2014). Interestingly, diets supplemented with phosphate glass with boron and $\mathrm{CaFB}$ significantly increase concentrations of boron in breast and breast fillet, as well as in the tibia of chicken broilers (Stef et al., 2014).

There are also studies showing that dietary boron supplementation stimulates eye development and structure in the zebrafish and frog adult offspring of the first generation (Fort et al., 1999a; Kot, 2009). It has also been revealed that diets enriched with boron affect serum or plasma contents of some hormones (like 17 $\beta$-estradiol, calcitonin, triiodothyronine or 25-hydroxycholecalciferol) involved in bone turnover in animals and humans (Nielsen, 2002; 2014; Uluisik et al., 2018). Thus, for humans, boron intakes of 1-3 mg per day have beneficial effects on bone and brain health (Nielsen, 2008).

Dietary boron has been proved to increase some steroid hormones, like testosterone or estrogens. Therefore, boron-rich diets may play important role in the prevention of some diseases such as osteoporosis and arthritis (Devirian and Volpe, 2003). Moreover, supra concentrations of boron in diets ( $\geq 10 \mathrm{mg} \mathrm{B} / \mathrm{kg}$ diet) increase plasma and testicular testosterone contents and temporarily increase the 1,25-hydroxycholecalciferol content in plasma of rats (Naghii and Samman, 1997). The 17 $\beta$-estradiol concentration in serum of perimenopausal women was also higher during the boron supplementation period than during the placebo period. Diets enriched in boron (10 mg B per day) also cause statistically significant increase of plasma estradiol contents and tend to increase plasma testosterone in male humans.

As a consequence, the boron-rich diets protect against prostate cancer. In fact, elevated levels of circulating estradiol and testosterone in male humans have been proposed to decrease prostate cancer risk. The concentration of boron in diets inversely correlated with risk of this type of cancer. Actually, the prostate cancer occurrence was one third smaller for men ingesting more than $1.8 \mathrm{mg}$ dietary B/day, relative to $0.9 \mathrm{mg}$ dietary B/day (Scorei, 2011). Experimental evidences show that dietary boron (as boric acid or borates) inhibits prostate cancer cell growth by decreasing cyclin A-E expression (Barranco and Eckhert, 2006). Moreover, it seems likely that dietary boron reduces prostate cancer risk 
through its influence on steroid hormones (especially androgens) (Scorei, 2011). Furthermore, in humans an increased boron consumption has been associated with a decreased incidence of several types of cancers (e.g., lung, cervical or breast cancer) (Hunt, 2008; Scorei, 2011). In fact, negative correlations have been found between the concentration of boron in diets and the incidence of lung cancer. It has been proved that in the case of postmenopausal women, $17 \beta$-estradiol may be used to decrease lung cancer risks associated with low estrogens concentrations. Fortunately, boron supplementation increased $17 \beta$-estradiol contents. Interestingly, high contents of boron in diets reduced lung cancer risks for smokers, whereas the highest risk exists in case of smokers with low concentrations of boron in diets (Mahabir et al., 2008). According to the recent studies, boron intake at a minimum of $10 \mathrm{mg}$ of $\mathrm{B} /$ day reduces the $17 \beta$-estradiol concentration, as well as increases the testosterone concentration. These regulations of sex steroid hormones assure a hormone-dependent protection against breast cancer (Naghii et al., 2011). Unfortunately, cervical cancer is the second most frequent cancer in women. Genetic, environmental, social and infectious factors (like human papilloma virus; HPV) are the main and generally known reasons for this cancer (Scorei, 2011). Boron exists in human body mostly in the form of boric acid, which is an inhibitor of serine proteases. It is thought that consumption of high doses of boron with drinkg water can reduce HPV transformation, thereby decreasing the risk of cervical cancer (Korkmaz et al., 2007). Thus, women with increased risk factors for cervical and breast cancers should increase their intake of boron-rich groceries (like broccoli, avocado, raisins and nuts), as well as supplement their diets with boron to decrease the risk of developing these two diseases. Interestingly, these women should increase their intake of food rich in boron (around $20 \mathrm{mg} \mathrm{B}$ per day) and n-3PUFA (i.e. an adequate 4:1 balance between n-6PUFA and n-3PUFA in nutrition). Also CaFB may have both preventive and therapeutic potential in cancers (Tepedelen et al., 2017).

\section{Effect of dietary boron on some enzymes and hormones in mammals}

Experimental nutrition studies document that dietary boron compounds (like borates) can affect the utilization or metabolism of many substances involved in crucial life processes, including $\mathrm{Mg}$, $\mathrm{Ca}, \mathrm{Cu}, \mathrm{N}$, glucose, triglycerides, reactive oxygen and nitrogen species, vitamin $\mathrm{D}_{3}$, insulin, thyroid hormone, estrogens or progesterone (Trifunovic and Larsson, 2008; Abdelnour et al., 2018). Boron compounds may play an important role in cell membrane functions, which affects response to hormone actions, transmembrane signalling and transmembrane movement of regulatory ions. Boron compounds may act as a metabolic regulator in some enzymatic systems (Nielsen, 2002; 2008; 2017; Sizmaz et al., 2017). Boron compounds can affect the composition of mammal body systems including muscles, blood, skeleton or the central nervous system (especially the brain) (Nielsen, 2002 ; 2008; 2014). Recent findings indicate that boron supplementation can facilitate insulin action. Subsequently, dietary boron compounds may prevent inflammatory disease because some key regulatory enzymes in the inflammatory response are inhibited by physiological amount of boron in diets (Hunt and Idso, 1999; Hunt, 2003; 2008). Dietary boron compounds play significant role in hormonal and mineral metabolism, cell membrane functions and enzyme reactions. Indeed, boron, in several chemical forms, has an impact on the activities of at least 26 enzymes, most of which are necessary for energy substrate metabolism in higher animals and humans (Hunt, 2003; 2008; 2012; Bozkurt and Küçükyilmaz, 2015). Moreover, there are numerous studies showing that dietary boron supplementation appears to have positive effects on the central nervous system (especially the brain) of mammals and on cognitive performance especially in older men and women (Nielsen, 2002; 2014; 2017; Kot, 2009). Interestingly, orally supplemented borates are used to treat epilepsy.

On the other hand, boron-deficient diets can contribute to a lack of energy, ability to stay focused on tasks and mental alertness. The electroencephalogram changes induced by inadequate boron intake are similar to that found in heavy metal toxicity (like mercury or lead) and non-specific malnutrition. Moreover, diets with low levels of boron reduce behavioural activation and mental alertness and are associated with weakened performance in psychomotor tasks and vigilance (Penland, 1998). Boron-deficient diets are related to decrease in electrical activity of brain and short-term memory, while diets supplemented with boron stimulate brain functions of higher animals and humans. The above mentioned effects could be attributed to changes in membranes providing nerve-impulse transmission by boron (Kot, 2009).

On the other hand, neurological disorders have been noted in humans after ingestion of high 
amounts of boron (U.S. Department of Health and Human Services, 2010). Newborn infants who ingested 4.5-14 g of boric acid or sodium tetraborate showed central nervous system (CNS) symptoms. A dose of $\sim 0.5 \mathrm{~g} \mathrm{~B} / \mathrm{kg}$ per day revealed CNS symptoms, like tremors, headaches, restlessness and convulsions followed by weakness, coma and death. Histological examination of infants revealed degenerative changes in brain neurons, congestion and brain and meninges oedema with perivascular haemorrhage and intravascular thrombosis.

Obesity and associated co-morbidities (like cancer, type 2 diabetes, hypertension, cardiovascular disease and posttraumatic stress disorder) are worldwide medical problems resulting in serious morbidity and mortality. However, dietary boron acid or borates were showed to reduce weight in experimental animals. Boron supplementation restrained the expression of adipogenesis-related genes and proteins (like peroxisome proliferatoractivated receptor $\gamma$ (PPAR $\gamma$ ) or CCAAT-enhancerbinding protein $\alpha$ ) by regulating decisive growth factors, $\beta$-catenin, a serine/threonine-specific protein kinase and extracellular signal-regulated kinase signalling pathways (Doğan et al., 2017). Furthermore, dietary boron depressed mitotic clonal expansion by regulation of cell cycle genes.

Most mutagenicity investigations show that boron is not genotoxic. In fact, results of mammalian mutagenicity studies are all negative. Boric acid or borates are ineffective in inducing unscheduled DNA biosynthesis in primary cultures of male F344 rat hepatocytes (Bakke, 1991). Similarly, boric acid does not induce mutations at the thymidine kinase locus in the L5178Y mouse lymphoma cells in, either the absence or presence, of a rat liver activation system (Rudd, 1991; U.S. Department of Health and Human Services, 2010). Furthermore, many boron compounds (like borax, boric acid, probertite and kernite) have a protective activity against genotoxic effects in cultured human lymphocytes (Geyikoglu and Turkez, 2008; Turkez et al., 2010).

Numerous studies show that boron supplementation may interfere with lipid metabolism in animals and humans (Nielsen, 2002; 2008; 2014; 2017; Bozkurt and Küçükyilmaz, 2015; Sizmaz et al., 2017). It is known that diets enriched with borate exert a protective effect against fatty liver disease (Basoglu et al. 2002; 2010). Dietary sodium borate (100 mg/kg BW per day) during early lactation of dairy cattle reduces the risk of fatty live development. Researchers have also indicted that diets enriched with sodium borate significantly decrease concentrations of total cholesterol, triglycerides, very low density lipoprotein, low-density lipoprotein, high-density lipoprotein, glucose, insulin, and non-esterified fatty acids in blood of dairy cattle during periparturient period (Basoglu et al., 2002; Kabu and Civelek, 2012). The precise molecular mechanisms underlying the anti-adipogenic activity of dietary boron are usually intangible. Analysis of the cellular components affected by boron in adipocytes may facilitate the development of more effective treatment modalities. One potential target is the $\mathrm{Ca}^{2+}$ balance inside mammal cells. Interestingly, boric acid or borates interact with $\mathrm{NAD}^{+}$and inhibit cyclic ADP ribose-activated $\mathrm{Ca}^{2+}$ release from ryanodine receptor, leading to decreased endoplasmic reticulum luminal $\mathrm{Ca}^{2+}$ concentrations (Henderson et al., 2015). Extracellular and intracellular $\mathrm{Ca}^{2+}$ homeostasis is decisive for almost all of steps of adipogenic differentiation (Meldolesi, 2008; Graham et al., 2009). The recent studies show that increasing concentrations of boric acid or sodium pentaborate considerably reduces lipid accumulation in mammal tissues in a concentration-dependent manner (Doğan et al., 2017).

Numerous investigations suggest the beneficial impact of dietary boric acid or borate supplementation in improving antioxidant defence mechanism (like catalase, superoxide dismutase, glucose-6-phosphate dehydrogenase, glutathioneS-transferase and glutathione peroxidase enzyme activities) thereby stimulating the ability of biological system to detoxify reactive intermediates (like reactive oxygen and nitrogen species) or to repair resulting damage (e.g., DNA damage or lipid peroxidation in mammals) (Ince et al., 2010; Celikezen et al., 2015; Boyacioglu et al., 2017; Uluisik et al., 2018). Therefore, dietary boron reduces heat stress in livestock species (Abdelnour et al., 2018). In tropical areas, high temperatures are a restraint to livestock production having the most damaging impact on physiological, productive and immunological variables (Abdelnour et al., 2018). Thus, high temperatures cause decline in livestock production.

Moreover, boron supplementation can decrease PUFA peroxidation by increasing the antioxidant enzyme activity and improving free radical clearance ability (Hu et al., 2014). Simultaneously, boron shows hepatoprotective and DNA damage preventing properties (Ince et al., 2014). Moreover, boric acid has antiseptic, antifungal and antiviral properties, and for these reasons is applied as water clarifier in swimming pool water treatment. Mild solutions of boric acid are used as eye antiseptics. 
Also, boron supplementation significantly increases the concentrations of total glutathione, its analogues, other neutralizing agents, as well as total antioxidant capacity (Türkez et al., 2007). In another study, it is suggested that reactive oxygen species formation in leukocytes may be reduced through the inhibitory actions of boron on 6-phospho-gluconate dehydrogenase.

Numerous studies document that dietary boron is implicated in immune system functioning (Hunt and Idso, 1999; Nielsen and Penland, 1999; Hunt, 2003; Vijay Bhasker et al., 2016). It has been found that boron supplementation affects the humoral immune response by stimulating antibody biosynthesis in response to dosed antigen in laboratory rats (Bozkurt and Küçükyilmaz, 2015). Laboratory rats fed a boron-deficient diet $(0.15 \mathrm{mg} \mathrm{B} / \mathrm{kg})$ had lower levels of anti-typhoid IgM and IgG titres in comparison with animals fed diets supplemented with boron following injection of typhoid vaccine. Thus, this finding indicates that boron supplementation may also affect the adaptive immune response (Bai et al., 1997). Moreover, the impact of boron supplementation on immune response may be associated with the ability of boron to change the biosynthesis efficiency of various cytokines (Hunt, 2003; Vijay Bhasker et al., 2016; Abdelnour et al., 2018).

\section{Conclusions}

Boron is a vital micro-element for plants and undoubtedly for animals and humans. This bioactive element has many beneficial physiological effects on living organisms at a low level; however boron is toxic at higher concentrations in diets. In vitro and in vivo animal and human studies have shown that boron is a bioactive element in nutritional amounts that can affect the utilization or metabolism of many substances involved in key life processes, including $\mathrm{Ca}, \mathrm{Mg}, \mathrm{P}, \mathrm{Cu}, \mathrm{N}$, glucose, triglyceride, reactive oxygen and nitrogen species, vitamin $\mathrm{D}_{3}$, insulin, thyroid hormone, estrogen or progesterone. Compounds containing boron may play an important role in the functioning of cell membrane, which affects the action of hormones, transmembrane signalling and transmembrane movement of regulatory ions. Especially organic boron compounds favourably induce bone growth and metabolism, the functioning of central nervous and immune systems, alleviate arthritic symptoms, facilitate hormone action and are associated with a reduced risk for some types of cancers. Boron reduces the risk of inflammatory diseases and also relieves heat stress. Besides, boron (in particular its organic compounds) is an effective natural antioxidant and detoxifying agent. Dietary boron intake has a positive impact on livestock production as well as health. Therefore, more in-depth research is needed to understand the true mechanisms of boron action in humans and animals, and to adopt boron requirements in different animal species.

\section{Acknowledgements}

This study was supported by the statutory funds from the Kielanowski Institute of Animal Physiology and Nutrition, Polish Academy of Sciences, Jabłonna, Poland.

\section{References}

Abdelnour S.A., Abd El-Hack M.E., SwelumA.A., Perillo A., Losacco C., 2018. The vital roles of boron in animal health and production: A comprehensive review. J. Trace Elem. Med. Biol. 50, 296-304, https://doi.org/10.1016/j.jtemb.2018.07.018

Armstrong T.A., Flowers W.L., Spears J.W., Nielsen F.H., 2002. Long-term effects of boron supplementation on reproductive characteristics and bone mechanical properties in gilts. J.Anim. Sci. 80, 154-161, https://doi.org/10.2527/2002.801154x

Armstrong T.A., Spears J.W., 2001. Effect of dietary boron on growth performance, calcium, and phosphorus metabolism, and bone mechanical properties in growing barrows. J. Anim. Sci. 79, 3120-3127, https://doi.org/10.2527/2001.79123120x

Armstrong T.A., Spears J.W., Crenshaw T.D., Nielsen F.H., 2000. Boron supplementation of a semipurified diet for weanling pigs improves feed efficiency and bone strength characteristics and alters plasma lipid metabolites. J. Nutr. 130, 2575-2581, https://doi.org/10.1093/jn/130.10.2575

Bai Y., Hunt C.D., Newman S.M., 1997. Dietary boron increases serum antibody ( $\lg G$ and $\lg M$ ) concentrations in rats immunized with human typhoid vaccine. Proc. North Dakota Acad. Sci. 51, p. 181

Baker S.J., Tomsho J.W., Benkovic S.J., 2011. Boron-containing inhibitors of synthetases. Chem. Soc. Rev. 40, 4279-4285, https://doi.org/10.1039/c0cs00131g

Bakke J.P., 1991. Evaluation of the potential of boric acid to induce unscheduled DNA synthesis in the in vitro hepatocyte DNA repair assay using the male F-344 rat. Submitted by U.S. Borax Corp; MRID No. 42038903

Barranco W.T., Eckhert C.D., 2006. Cellular changes in boric acid treated DU-145 prostate cancer cells. Br. J. Cancer 94, 884-890, https://doi.org/10.1038/sj.bjc.6603009

Basoglu A., Baspinar N., Sagkan OzturkA., PekerAkalin P., 2010. Effects of boron administration on hepatic steatosis, hematological and biochemical profiles in obese rabbits. Trace Elem. Electrolytes 27, 225-231, https://doi.org/10.5414/TEP27225

Basoglu A., Sevinç M., Birdane F.M., Boydak M., 2002. Efficacy of sodium borate in the prevention of fatty liver in dairy cows. J. Vet. Intern. Med. 16, 732-735, https://doi. org/10.1111/j.1939-1676.2002.tb02416.x

Białek M., Czauderna M., Białek A., 2017. Conjugated linolenic acid (CLnA) isomers as new bioactive lipid compounds in ruminant-derived food products. A review. J. Anim. Feed Sci. 26, 3-17, https://doi.org/10.22358/jafs/68862/2017 
Blevins D.G., Lukaszewski K.M., 1998. Boron in plant structure and function. Annu. Rev. Plant Physiol. Plant Molec. Biol. 49, 481-500, https://doi.org/10.1146/annurev.arplant.49.1.481

Bolaños L., Lukaszewski K., Bonilla I., Blevins D., 2004. Why boron? Plant Physiol. Biochem. 42, 907-912, https://doi. org/10.1016/j.plaphy.2004.11.002

Boyacioglu S.O., Korkmaz M., Kahraman E., Yildirim H., Bora S., Ataman O.Y., 2017. Biological effects of tolerable level chronic boron intake on transcription factors. J. Trace Elem. Med. Biol. 39, 30-35, https://doi.org/10.1016/j.jtemb.2016.06.009

Bozkurt M., Küçükyilmaz K., 2015. An evaluation on the potential role of boron in poultry nutrition. Part I: Production performance. Worlds Poult. Sci. J. 71, 327-338, https://doi.org/10.1017/ S0043933915000331

Brown T.F., McCormick M.E., Morris D.R., Zeringue L.K., 1989. Effects of dietary boron on mineral balance in sheep. Nutr. Res. 9, 503-512, https://doi.org/10.1016/S0271-5317(89)80175-7

Celikezen F.C., Turkez H., Aydin E., Izgi M.S., Celikezen B., 2015. Potent antioxidant and genotoxic effects of ammonium tetra borate in vitro. Nat. Sci. Discov. 1, 45-49, https://doi. org/10.20863/nsd.06412

Czauderna M., Białek M., Krajewska K.A., Ruszczyńska A., Bulska E., 2017. Selenium supplementation into diets containing carnosic acid, fish and rapeseed oils affects the chemical profile of whole blood in lambs. J. Anim. Feed Sci. 26, 192-203, https://doi.org/10.22358/jafs/76594/2017

Davidson M.G., Wade K., Marder T.B., Hughes A.K. (Editors), 2000. Contemporary Boron Chemistry. Royal Society of Chemistry. London(UK), pp. 538, https://doi.org/10.1039/9781847550644

Dessordi R., Spirlandeli A.L., Zamarioli A., Volpon J.B., Navarro A.M., 2017. Boron supplementation improves bone health of nonobese diabetic mice. J. Trace Elem. Med. Biol. 39, 169-175, https://doi.org/10.1016/j.jtemb.2016.09.011

Devirian T.A., Volpe S.L., 2003. The physiological effects of dietary boron. Crit. Rev. Food Sci. Nutr. 43, 219-231, https://doi. org/10.1080/10408690390826491

Doğan A., Demirci S., Apdik H., Bayrak O.F., Gulluoglu S., Tuysuz E.C., Gusev O., Rizvanov A.A., Nikerel E., Şahin F., 2017. A new hope for obesity management: Boron inhibits adipogenesis in progenitor cells through the $W n t / \beta$-catenin pathway. Metabolism 69, 130-142, https://doi.org/10.1016/j. metabol.2017.01.021

Donoiu I., Militaru C., Obleagă O., Hunter J.M., Neamţu J., Biţă A., Scorei I.R., Rogoveanu O.C., 2018. Effects of boron-containing compounds on cardiovascular disease risk factors - a review. J. Trace Elem. Med. Biol. 50, 47-56, https://doi.org/10.1016/j.jtemb.2018.06.003

EPA (U.S. Environmental Protection Agency), 2004. Toxicological Review of Boron and Compounds. EPA 635/04/052, https://cfpub.epa.gov/ncea/iris/iris_documents/documents/ toxreviews/0410tr.pdf

Fort D.J., Stover E.L., Strong P.L., Murray F.J., 1999b. Effect of boron deprivation on reproductive parameters in Xenopus laevis. J. Trace Elem. Exp. Med. 12, 187-204, https://doi.org/10.1002/ (SICI)1520-670X(1999)12:3<187::AID-JTRA3>3.0.CO;2-J

Fort D.J., Stover E.L., Strong P.L., Murray F.J., Keen C.L., 1999a. Chronic feeding of a low boron diet adversely affects reproduction and development in Xenopus laevis. J. Nutr. 129, 2055-2060, https://doi.org/10.1093/jn/129.11.2055

Fry R.S., Lloyd K.E., Jacobi S.K., Siciliano P.D., Robarge W.P., Spears J.W., 2010. Effect of dietary boron on immune function in growing beef steers. J. Anim. Physiol. Anim. Nutr. 94, 273-279, https://doi.org/10.1111/j.1439-0396.2008.00906.x
Geyikoglu F., Turkez H., 2008. Boron compounds reduce vanadium tetraoxide genotoxicity in human lymphocytes. Environ. Toxicol. Pharmacol. 26, 342-347, https://doi.org/10.1016/j. etap.2008.07.002

Graham S.J.L., Black M.J., Soboloff J., Gill D.L., Dziadek M.A., Johnstone L.S., 2009. Stim1, an endoplasmic reticulum $\mathrm{Ca}^{2+}$ sensor, negatively regulates 3T3-L1 pre-adipocyte differentiation. Differentiation 77, 239-247, https://doi. org/10.1016/j.diff.2008.10.013

Hakki S.S., Dundar N., Kayis S.A., Hakki E.E., Hamurcu M., Kerimoglu U., Baspinar N., Basoglu A., Nielsen F.H., 2013. Boron enhances strength and alters mineral composition of bone in rabbits fed a high energy diet. J. Trace Elem. Med. Biol. 27, 148-153, https://doi.org/10.1016/j.jtemb.2012.07.001

Henderson K.A., Kobylewski S.E., Yamada K.E., Eckhert C.D., 2015. Boric acid induces cytoplasmic stress granule formation, elF2a phosphorylation, and ATF4 in prostate DU-145 cells. Biometals 28, 133-141, https://doi.org/10.1007/s10534-0149809-5

Hopewell J.W., Morris G.M., Schwint A., Coderre J.A., 2011. The radiobiological principles of boron neutron capture therapy: a critical review. Appl. Radiat. Isot. 69, 1756-1759, https://doi. org/10.1016/j.apradiso.2011.04.019

Horiguchi H., Sato T., Kumada H., Yamamoto T., Sakae T., 2015. Estimation of relative biological effectiveness for boron neutron capture therapy using the PHITS code coupled with a microdosimetric kinetic model. J. Radiat. Res. 56, 382-390, https://doi.org/10.1093/jrr/rru109

Hu Q., Li S., Qiao E., Tang Z., Jin E., Jin G., Gu Y., 2014. Effects of boron on structure and antioxidative activities of spleen in rats. Biol. Trace Elem. Res. 158, 73-80, https://doi. org/10.1007/s12011-014-9899-5

Hunt C.D., 1998. Regulation of enzymatic activity: One possible role of dietary boron in higher animals and humans. Biol. Trace Elem. Res. 66, 205-225, https://doi.org/10.1007/BF02783139

Hunt C.D., 2003. Dietary boron: An overview of the evidence for its role in immune function. J. Trace Elem. Exp. Med. 16, 291-306, https://doi.org/10.1002/jtra.10041

Hunt C.D., 2008. Dietary boron: Possible roles in human and animal physiology. Biomed. Res. Trace Elem. 19, 243-253

Hunt C.D., 2012. Dietary boron: Progress in establishing essential roles in human physiology. J. Trace Elem. Med. Biol. 26, 157-160, https://doi.org/10.1016/j.jtemb.2012.03.014

Hunt C.D., Idso J.P., 1999. Dietary boron as a physiological regulator of the normal inflammatory response: a review and current research progress. J. Trace Elem. Exp. Med. 12, 221-233, https://doi.org/10.1002/(SICl)1520670X(1999)12:3<221::AID-JTRA6>3.0.CO;2-X

Hunter J.M., Nemzer B.V., Rangavajla N. et al., 2019. The fructoborates: Part of a family of naturally occurring sugarborate complexes - biochemistry, physiology, and impact on human health: a review. Biol. Trace Elem. Res. 188, 11-25, 11-25, https://doi.org/10.1007/s12011-018-1550-4

Ince S., Kucukkurt I., Cigerci I.H., Fidan A.F., Eryavuz A., 2010. The effects of dietary boric acid and borax supplementation on lipid peroxidation, antioxidant activity, and DNA damage in rats. J. Trace Elem. Med. Biol. 24, 161-164, https://doi. org/10.1016/j.jtemb.2010.01.003

Ince S., Kucukkurt I., Demirel H.H., Acaroz D.A., Akbel E., Cigerci I.H., 2014. Protective effects of boron on cyclophosphamide induced lipid peroxidation and genotoxicity in rats. Chemosphere 108, 197-204, https://doi.org/10.1016/j.chemosphere.2014.01.038 
Jin E., Gu Y., Wang J., Jin G., Li S., 2014. Effect of supplementation of drinking water with different levels of boron on performance and immune organ parameters of broilers. Ital. J. Anim. Sci. 13, 204-214, https://doi.org/10.4081/ijas.2014.3152

Kabata-Pendias A., 2000. Trace Elements in Soils and Plants. $3^{\text {rd }}$ Edition. CRC Press. Boca Raton, FL (USA), pp. 169-179, https://doi.org/10.1201/9781420039900

Kabu M., Akosman M.S., 2013. Biological effects of boron. In: D.M. Whitacre (Editor). Reviews of Environmental Contamination and Toxicology, Volume 225. Springer Science+Business Media. New York, NY (USA), pp. 57-75, https://doi.org/10.1007/978-1-4614-6470-9_2

Kabu M., Birdane F.M., Civelek T., Uyarlar C., 2013. Effects of boron administration on serum $\mathrm{Ca}, \mathrm{Mg}$ and $\mathrm{P}$ for peripartum cows. Arch. Tierz. 56, 733-741, https://doi.org/10.7482/0003-943856-073

Kabu M., Civelek T., 2012. Effects of propylene glycol, methionine and sodium borate on metabolic profile in dairy cattle during periparturient period. Rev. Med. Vet. 163, 419-430

Kabu M., Uyarlar C., Żarczyńska K., Milewska W., Sobiech P., 2015. The role of boron in animal health. J. Elem. 20, 535-541, https://doi.org/10.5601/jelem.2014.19.3.706

Korkmaz M., Uzgören E., Bakırdere S., Aydın F., Ataman O.Y., 2007. Effects of dietary boron on cervical cytopathology and on micronucleus frequency in exfoliated buccal cells. Environ. Toxicol. 22, 17-25, https://doi.org/10.1002/tox.20229

Kot F.S., 2009. Boron sources, speciation and its potential impact on health. Rev. Environ. Sci. Bio/Technol. 8, 3-28, https://doi. org/10.1007/s11157-008-9140-0

Lanoue L., Taubeneck M.W., Muniz J., Hanna L.A., Strong P.L., Murray F.J., Nielsen F.H., Hunt C.D., Keen C.L., 1998. Assessing the effects of low boron diets on embryonic and fetal development in rodents using in vitro and in vivo model systems. Biol. Trace Elem. Res. 66, 271-298, https://doi.org/10.1007/BF02783143

Litovitz T.L., Klein-Schwartz W., Oderda G.M., Schmitz B.F., 1988. Clinical manifestations of toxicity in a series of 784 boric acid ingestions. Am. J. Emerg. Med. 6, 209-213, https://doi. org/10.1016/0735-6757(88)90001-0

Mahabir S., Spitz M.R., Barrera S.L., Dong Y.Q., Eastham C., Forman M.R., 2008. Dietary boron and hormone replacement therapy as risk factors for lung cancer in women. Am. J. Epidemiol. 167, 1070-1080, https://doi.org/10.1093/aje/kwn021

Meldolesi J., 2008. Inhibition of adipogenesis: a new job for the ER $\mathrm{Ca}^{2+}$ pool. J. Cell Biol. 182, 11-13, https://doi.org/10.1083/ jcb.200805110

Militaru C., Donoiu I., Craciun A., Scorei I.D., Bulearca A.M., Scorei R.I., 2013. Oral resveratrol and calcium fructoborate supplementation in subjects with stable angina pectoris: effects on lipid profiles, inflammation markers, and quality of life. Nutrition 29, 178-183, https://doi.org/10.1016/j. nut.2012.07.006

Mogoşanu G.D., BiţăA., Bejenaru L.E. et al., 2016. Calcium fructoborate for bone and ccardiovascular health. Biol. Trace Elem. Res. 172, 277-281, https://doi.org/10.1007/s12011-015-0590-2

Naghii M.R., Mofid M., Asgari A.R., Hedayati M., Daneshpour M.S., 2011. Comparative effects of daily and weekly boron supplementation on plasma steroid hormones and proinflammatory cytokines. J. Trace Elem. Med. Biol. 25, 54-58, https://doi.org/10.1016/j.jtemb.2010.10.001

Naghii M.R., Samman S., 1996. The effect of boron supplementation on the distribution of boron in selected tissues and on testosterone synthesis in rats. J. Nutr. Biochem. 7, 507-512, https://doi.org/10.1016/0955-2863(96)00102-7
Naghii M.R., Samman S., 1997. The effect of boron on plasma testosterone and plasma lipids in rats. Nutr. Res. 17, 523-531, https://doi.org/10.1016/S0271-5317(97)00017-1

Nielsen F.H., 2002. The nutritional importance and pharmacological potential of boron for higher animals and human. In: H.E. Goldbach, B. Rerkasem, M.A. Wimmer, P.H. Brown, M. Thellier, W.R. Bell (Editors). Boron in Plant and Animal Nutrition. Springer Science+Business Media. New York, NY (USA), pp. 37-50, https://doi.org/10.1007/978-1-4615-0607-2

Nielsen F.H., 2008. Is boron nutritionally relevant? Nutr. Rev. 66, 183-191, https://doi.org/10.1111/j.1753-4887.2008.00023.x

Nielsen F.H., 2014. Update on human health effects of boron. J. Trace Elem. Med. Biol. 28, 283-287, https://doi.org/10.1016/j. jtemb.2014.06.023

Nielsen F.H., 2017. Historical and recent aspects of boron in human and animal health. J. Boron 2, 153-160

Nielsen F.H., Penland J.G., 1999. Boron supplementation of perimenopausal women affects boron metabolism and indices associated with macromineral metabolism, hormonal status and immune function. J. Trace Elem. Exp. Med. 12, 251-261, https://doi.org/10.1002/(SICI)1520670X(1999)12:3<251::AID-JTRA8>3.0.CO;2-I

Palacios C., 2006. The role of nutrients in bone health, from A to Z. Crit. Rev. Food Sci. Nutr. 46, 621-628, https://doi. org/10.1080/10408390500466174

Penland J.P., 1998. The importance of boron nutrition for brain and psychological function. Biol. Trace Elem. Res. 66, 299-317, https://doi.org/10.1007/BF02783144

Pietrzkowski Z., Phelan M.J., Keller R., Shu C., Argumedo R., Reyes-Izquierdo T., 2014. Short-term efficacy of calcium fructoborate on subjects with knee discomfort: a comparative, double-blind, placebo-controlled clinical study. Clin. Interv. Aging. 2017, 895-899, https://doi.org/10.2147/CIA.S64590

Pietrzkowski Z., Roldán Mercado-Sesma A., Argumedo R., Cervantes M., Nemzer B., Reyes-Izquierdo T., 2018. Effects of once-daily versus twice daily dosing of calcium fructoborate on knee discomfort. A 90-day, double-blind, placebo controlled randomized clinical study. J. Aging Res. Clin. Pract. 7, 31-36, https://doi.org/10.14283/jarcp.2018.7

Pizzorno L., 2015. Nothing boring about boron. Integr. Med. (Encinitas) $14,35-48$

Restuccio A., Mortensen M.E., Kelley M.T., 1992. Fatal ingestion of boric acid in an adult. Am. J. Emerg. Med. 10, 545-547, https://doi.org/10.1016/0735-6757(92)90180-6

Rogoveanu O.C., Mogoşanu G.D., Bejenaru C. et al., 2015. Effects of calcium fructoborate on levels of $C$-reactive protein, total cholesterol, low-density lipoprotein, triglycerides, IL-1 $\beta$, IL-6, and MCP-1: a double-blind, placebo-controlled clinical study. Biol. Trace Elem. Res. 163, 124-131, https://doi.org/10.1007/ s12011-014-0155-9

Rondanelli M., Opizzi A., Perna S., Faliva M.A., 2013. Update on nutrients involved in maintaining healthy bone. Endocrinol. Nutr. 60, 197-210, https://doi.org/10.1016/j. endonu.2012.09.006

Rozbicka-Wieczorek A.J., Czauderna M., Więsyk E., Radzik-Rant A., 2016. Selenium species in diet containing carnosic acid, fish and rapeseed oils affect fatty acid profiles in lamb muscles. J. Anim. Feed Sci. 25, 216-225, https://doi.org/10.22358/ jafs/65555/2016

Rudd C.J., 1991. Mouse lymphoma cell mutagenesis assay (tK+/-/ tK-/-) of boric acid. Submitted by U.S. Borax Corp. MRID No. 4203902 
Scorei R.I., 2011. Boron compounds in the breast cancer cells chemoprevention and chemotherapy. In: E. Gunduz (Editor). Breast Cancer - Current and Alternative Therapeutic Modalities. IntechOpen Ltd. London (UK), pp. 91-114, https:// doi.org/10.5772/20405

Scorei R.I., Rotaru P., 2011. Calcium fructoborate - potential antiinflammatory agent. Biol. Trace Elem. Res. 143, 1223-1238, https://doi.org/10.1007/s12011-011-8972-6

Sizmaz O., Koksal B.H., Yildiz G., 2017. Rumen microbial fermentation, protozoan abundance and boron availability in yearling rams fed diets with different boron concentrations. J. Anim. Feed Sci. 26, 59-64, https://doi.org/10.22358/jafs/69038/2017

Soriano-Ursúa M.A., Das B.C., Trujillo-Ferrara J.G., 2014. Boron containing compounds: chemico-biological properties and expanding medicinal potential in prevention, diagnosis and therapy. Expert Opin. Ther. Patents 24, 485-500, https://doi. org/10.1517/13543776.2014.881472

Stef L., Drinceanu D., Stef D.S., Peţ I., Peţ E., Simiz E., 2014. Effects of new mineral sources for boron supplementation on meat quality in broilers. Roman. Biotechnol. Lett. 19, 9585-9596

Sun P., Luo Y., Wu X.T., Ansari A.R., Wang J., Yang K., Xiao K., Peng K., 2016. Effects of supplemental boron on intestinal proliferation and apoptosis in African ostrich chicks. Int. J. Morphol. 34, 830-835, https://doi.org/10.4067/S071795022016000300002

Tanaka M., Fujiwara T., 2008. Physiological roles and transport mechanisms of boron: perspectives from plants. Pflugers Arch. 456, 671-677, https://doi.org/10.1007/s00424-0070370-8

Tepedelen B.E., Korkmaz M., Tatlisumak E., Uluer E.T., Ölmez E., Değerli İ., Soya E., İnan S., 2017. A study on the anticarcinogenic effects of calcium fructoborate. Biol. Trace Elem. Res. 178, 210-217, https://doi.org/10.1007/s12011016-0918-6

Trifunovic A., Larsson N.-G., 2008. Mitochondrial dysfunction as a cause of ageing. J. Intern. Med. 263, 167-178, https://doi. org/10.1111/j.1365-2796.2007.01905.x
Türkez H., Geyikoğlu F., Tatar A., Keleş S., Ozkan A., 2007. Effects of some boron compounds on peripheral human blood. Z. Naturforsch. C 62, 889-896, https://doi.org/10.1515/znc2007-11-1218

Turkez H., Tatar A., Hacımuftuoglu A., Ozdemir E., 2010. Boric acid as a protector against paclitaxel genotoxicity. Acta Biochim. Pol. 57, 95-97, https://doi.org/10.18388/abp.2010_2378

U.S. Department of Health and Human Services, 2010. Toxicological Profile for Boron. Agency for Toxic Substances and Disease Registry. Atlanta, GA (USA), pp. 248, https://www.atsdr.cdc. gov/toxprofiles/tp26.pdf

Uluisik I., Karakaya H.C., Koc A., 2018. The importance of boron in biological systems. J. Trace Elem. Med. Biol. 45, 156-162, https://doi.org/10.1016/j.jtemb.2017.10.008

Van Paemel M., Dierick N., Janssens G., Fievez V., De Smet S., 2010. Selected trace and ultratrace elements: Biological role, content in feed and requirements in animal nutrition - Elements for risk assessment. European Food Safety Authority (EFSA). Question No EFSA-Q-2008-04990, https:// doi.org/10.2903/sp.efsa.2010.EN-68

Vijay Bhasker T., Gowda N.K.S., Mondal S., Krishnamoorthy P., Pal D.T., Mor A., Karthik Bhat S., Pattanaik A.K., 2016. Boron influences immune and antioxidant responses by modulating hepatic superoxide dismutase activity under calcium deficit abiotic stress in Wistar rats. J. Trace Elem. Med. Biol. 36, 73-79, https://doi.org/10.1016/j.jtemb.2016.04.007

Wang W., Xiao K., Zheng X., Zhu D., Yang Z., Tang J., Sun P., Wang J., Peng K., 2014. Effects of supplemental boron on growth performance and meat quality in African ostrich chicks. J. Agric. Food Chem. 62, 11024-11029, https://doi. org/10.1021/j5501789t

WHO (World Health Organization), 1996. Trace Elements in Human Nutrition and Health. World Health Organization. Genova (Italy), pp. 361 